\title{
Estimation of heritabilities, genetic correlations, phenotypic correlations and genetic trends for production and reproduction traits of Holstein-Friesian dairy cattle using sire model
}

\author{
Osman M. M., Khairy M. El-Bayomi ${ }^{1}$ and Sherif A. Moawed \\ Department of Animal wealth Development, Faculty of Veterinary Medicine, Suez Canal University, \\ Ismailia, Egypt. \\ ${ }^{1}$ Department of Animal Wealth Development, Faculty of Veterinary Medicine, Zagazig University, \\ Zagazig, Egypt.
}

\begin{abstract}
A total of 3460 lactation records that represented 1059 dairy Holstein-Friesian cows were used in the present study that aimed to estimate genetic parameters such as heritability, genetic correlations, phenotypic correlations and genetic trends for some productive and reproductive traits. Studied traits were total milk yield, days in milk, fat $\%$, protein $\%$, dry period, age at first calving, number of services per conception, days open and calving interval. Data were collected from Egyptian Copenhagen Company in Alexandria-Cairo desert road for cows calved from 1998 to 2010. Least square analysis of mixed sire model was used in analysis using Harvey (1990) program. Heritability estimates were high for all traits and very high for fat and protein \% that exceeded 0.83 in two lactations. Genetic correlations were higher than phenotypic correlations and were high especially among production traits. Regression coefficients of genetic trends were positive for all studied traits except for days in milk and days open (in second lactation) and age at first calving. Generally, the current results showed genetic improvement of most of traits that reflect the efficiency of selection programs.
\end{abstract}

Keywords: dairy cattle, genetic parameters, genetic trends, sire models.

\section{INTRODUCTION}

Knowledge of genetic and phenotypic parameters is required for planning efficient breeding programs in animal husbandry. Two of these parameters are heritability and correlations. The first explains the extent to which observed differences between individuals are associated with additive genetic variance (the variance of the breeding values). With knowledge of this parameter, animal geneticists can determine whether or not a particular trait can be improved by selection, by improvement of management practices, or both. The second is defined as the correlations between two traits or two breeding values of traits (Roman, Wilcox and Martin, 2000).

Precise and accurate knowledge of genetic parameters are of paramount importance for planning appropriate selection and breeding strategies for the genetic improvement of dairy animals (Choudhary et al, 2003). An important aspect of formulation of breeding plan for animal or plant improvement is selection which amounts to choice of parents to produce the next generation. A basic prerequisite to the planning of breeding program is that of the total variability existing in the population and how much of this is caused by differences in the genetic make-up of the individuals. A quantitative measure of this is provided by heritability. With the help of heritability one can predict the breeding value of the individual. The magnitude of heritability dictates the choice of the selection method and breeding system (Paul et al, 2003). In addition, a goal of dairy cattle breeder is to increase genetic merit of milk production to determine the effectiveness of breeding programs. Genetic trends in dairy 
cattle population must be monitored. The present study was aimed to estimate heritabilities, genetic correlations, phenotypic correlations and genetic trends for different productive and reproductive traits of dairy cattle using sire models.

\section{MATERIAL AND METHODS}

Data collection:

Data of the present study were collected from a commercial dairy herd situated in CairoAlexandria desert road and named AlexandriaCopenhagen Company far from Alexandria by about $76 \mathrm{~km}$. Data of productive and reproductive records of Holstein Friesian cows were obtained and represented the period from 1998 to 2010 . The total number of lactation records was 3460 of 1059 dairy cows which were sired by 96 sires and of 513 dams. Productive traits studied were total milk yield (TMY), fat percentage (FP), protein percentage (PP), days in milk (DIM) and dry period (DP) while the reproductive traits were age at first calving (AFC), days open (DO), calving interval (CI) and number of services per conception (NSC). Records involved in analysis represented the first two lactations.

Estimation of heritability:

Heritability estimates for different traits were calculated based on half-sib method according to Becker (1984). The half-sib method performs random effects analysis of variance (ANOVA) for data from an experiment with nested design in the following form:

$\mathbf{Y}_{\mathrm{ij}}=\boldsymbol{\mu}+\boldsymbol{\alpha}_{\mathrm{i}}+\mathbf{e}_{\mathrm{ij}}$

This is a random effects model for data from a completely nested design where:

$\mathbf{Y}_{\mathrm{ij}}$ : The record of the $\mathrm{j}^{\text {th }}$ cow, $\left(\mathrm{j}^{\text {th }}=\right.$ number of the cow),

$\boldsymbol{\mu} \quad$ : Overall mean of the reference population, $\boldsymbol{\alpha}_{\mathrm{i}} \quad$ : Random effect due to $\mathrm{i}^{\text {th }}$ sire $\left(\mathrm{i}^{\text {th }}=\right.$ number of the sire),

e ij : The uncontrolled environmental and genetic deviations attributable to the individuals, All effects are random, normal and independent with expectations equal to zero. $\left(\alpha_{i}\right.$ and $e_{i j}$ are mutually uncorrelated random effects with mean zero and variance components as $\left(\sigma_{\alpha}^{2}\right.$ and $\left.\sigma_{e}^{2}\right)$, respectively. From this model, variance components $\left(\sigma^{2} S\right.$ and $\left.\sigma^{2}{ }_{w}\right)$ and heritabilities $\left(\mathrm{h}_{\mathrm{s}}^{2}\right)$ were estimated as follows:

$\mathbf{h}^{2}=\frac{\mathbf{4} \boldsymbol{\sigma}^{2} \mathbf{s}}{\boldsymbol{\sigma}^{2} \mathbf{s}+\boldsymbol{\sigma}^{\mathbf{2}} \mathbf{w}}$
$\mathbf{h}^{2} \mathbf{s}:$ heritability estimate due to sire,
$\boldsymbol{\sigma}^{2}{ }_{\mathrm{s}}:$ : Variance due to sire,
$\boldsymbol{\sigma}^{2}{ }_{\mathrm{w}}:$ : variance due to progeny.

Estimation of phenotypic and genetic correlations:

Phenotypic correlation $\left(r_{p}\right)$ is an estimate of the association between two visible traits in the current flock. Like the phenotype, or observed value, phenotypic correlations also contain both genetic and environmental effects. The phenotypic correlations between traits $X_{1}$ and $\mathrm{X}_{2}$ can be calculated according to Turner and Young (1969) as follows:

$r_{p}=\frac{\operatorname{Cov}\left(x_{1} x_{2}\right)}{\sqrt{\sigma^{2} x_{1}} \sqrt{\sigma^{2} x_{2}}}$

On the other hand, the genetic correlation is the correlation between breeding values. It is an estimate of the way in which selection of parents for one trait will cause a change in a second trait in the progeny. According to Legates and Warwick (1990), the genetic correlation is defined as the correlation between the additive breeding values of two traits $\left(g_{1}\right.$ and $\mathrm{g}_{2}$ ) or between the sums of the additive effects of the genes influencing these two traits and presented as:

$\mathbf{r g l g}_{2}=\frac{\operatorname{Cov~}_{1} g_{2}}{\sqrt{\left(\operatorname{Var} g_{1}\right)\left(\operatorname{varg}_{2}\right)}}$

$\operatorname{Cov} \mathbf{g}_{1} \mathbf{g}_{2}=$ genetic covariances between the additive breeding values for trait $\mathrm{g}_{1}$ and $\mathrm{g}_{2}$.

$\operatorname{Var} \mathbf{g}_{1}$ and $\operatorname{var} \mathbf{g}_{2}=$ genetic variances for the two traits.

Genetic trends of traits:

After calculating breeding values for trait, average of breeding values of animals for that trait on that year were calculated. Regression 
analysis was used to determine the significance of genetic trend using SPSS (16.0) for windows. Genetic trends were computed as the regression of estimated breeding values on their birth dates for cows born between 1998 and 2010. The following equation was used:

$\mathbf{Y}_{\mathbf{i}}=\mathbf{a}+\mathbf{b} \mathbf{X}_{\mathbf{i}}$

$\mathbf{Y}_{\mathbf{i}}=$ Estimated breeding value of trait,

$\mathbf{b}=$ Genetic trend,

$\mathbf{X}_{\mathbf{i}}=$ Year of calving,

$\mathbf{a}=$ Genetic gain .

Statistical models:

Data were statistically analyzed using the Least Squares Mixed Model and Maximum Likelihood (LSMLMW) computer program of Harvey (1990). Data of milk production and reproduction traits were analyzed using the following statistical mixed models for estimation of genetic parameters:

$\mathbf{Y}_{\mathrm{ijklmn}}=\boldsymbol{\mu}+\mathbf{S}_{\mathrm{i}}+\mathbf{Y r}_{\mathbf{j}}+\mathbf{M}_{\mathrm{k}}+\beta_{\mathbf{L} 1}\left(\mathrm{AFC}_{\mathrm{L}}\right)+\beta_{\mathrm{Q} 1}$ $\left(\mathrm{AFC}_{\mathrm{L}}\right)^{2}+\beta_{\mathrm{L} 2}\left(\mathrm{DO}_{\mathrm{m}}\right)+\beta_{\mathrm{Q} 2}\left(\mathrm{DO}_{\mathrm{m}}\right)^{2}+\mathrm{e}_{\mathrm{ijklmn}}$ (model 1)

$\mathbf{Y}_{\mathbf{i j k l m n}}=\boldsymbol{\mu}+\mathbf{S}_{\mathbf{i}}+\mathbf{Y r}_{\mathbf{j}}+\mathbf{M}_{\mathbf{k}}+\beta_{\mathbf{L} 1}\left(\mathrm{AFC}_{\mathbf{L}}\right)+\beta_{\mathbf{Q} 1}$ $\left(\text { AFCL }_{L}\right)^{2}+\beta_{L 2}\left(\right.$ TMY $\left._{m}\right)+\beta_{\text {Q2 }}\left(\text { TMY }_{m}\right)^{2}+$ $\mathbf{e}_{\mathrm{ijklmn}}(\operatorname{model} 2)$

Model (1) was used for analysis of productive traits, while model (2) was used for reproductive traits, where:

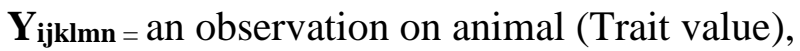
$\boldsymbol{\mu}=$ overall mean (mean of trait in population),

$S_{i}=$ random effect of $i^{\text {th }}$ sire $(i=1-96)$,

$\mathbf{Y} \mathbf{r}_{\mathbf{j}}=$ fixed effect of year of calving $\mathbf{j}(\mathrm{j}=1998$, 1999,..., 2010),

$\mathbf{M}_{\mathbf{k}}=$ fixed effect of month of calving ( $k=$ January, February,..., December),

$\beta_{\mathbf{L 1}}=$ linear regression coefficient for age at first calving,

$\mathbf{A F C}_{\mathbf{L}}=$ covariable of age at first calving (month),

$\beta_{\mathbf{Q} 1}=$ quadratic regression coefficient for age at first calving,

$\beta \mathbf{L}_{\mathbf{2}}=$ linear regression coefficient for days open and total milk yield,

$\mathbf{D O}_{\mathrm{m}}=$ covariable of days open,

$\mathbf{T M Y}_{\mathrm{m}}=$ covariable of total milk yield, $\beta \mathbf{Q 2}_{2}=$ quadratic regression coefficient for days open and total milk yield,

$\mathbf{e}_{\mathrm{ijk} \mathbf{m} n}=$ Residual error and assumed to be independently, randomly distributed with mean zero.

\section{RESULTS AND DISCUSSION}

1. Estimation of genetic parameters:

The estimates of heritabilities and their standard errors of milk production and fertility traits in Holstein-Friesian cows were presented in Tables (1 and 2) and the estimates were recorded for the first and second lactations. In the present study regarding this point, we want to explain, does the genetics behind each lactation were the same or different.

1.1. Heritability estimates of milk traits:

Heritability estimates for total milk yield were $0.29 \pm 0.09$ and $0.49 \pm 0.11$ for the first, second lactations, respectively. The values were medium in first parity, slightly high in second parity. It can be noticed that heritability values increased with increasing lactation number in contrast to the findings of Berger et al (1981) and Carlen et al (2004). The estimates of heritability of milk yield in general, were higher than those reported by Dong and Van Vleck (1989); Albuquerque (1999); Strabel and Jamrozik (2006); Lakshmi et al. (2009); Ayied et al (2011).

On the other hand, these estimates were lower the findings of Petersen et al (1986) in first lactation who found heritability value as 0.68 and Cilek and Sahin (2009) in first lactation. Moreover, the heritability values of this study are to near the estimates of Aydin (1996) in second lactation. Similar to the conclusion of Van Vleck et al (1988), the heritability estimates of milk yield and its composition may increase as the production level of herd was high. Thus, the variability of the herd could be attributed to the use of large number of sires. In later lactations, the number of records decreased, and subsequently, the result was increased value of standard error of estimates.

The Over estimates (very high estimates) of heritabilities obtained from sire model could be due to Sample size, culling and selection in the 
farm, absence of dam in the model, some sort of cofounding occurring in the model, the structure of data analyzed. The higher heritability estimates for milk traits in the present study indicated that the correlation between phenotype and genotype of the individual was high and therefore, selection on the basis of the individual's own phenotype should be effective. Direct selection for milk traits should be considered in selection program.

1.2. Heritability estimates of milk fat and protein:

Heritability estimates for fat \% were $0.90 \pm 0.15$ and $0.97 \pm 0.15$ and were $0.95 \pm 0.14,0.84 \pm 0.13$ for protein \% for first, second lactations, respectively. Similar to the finding of Campos et al. (1994), the estimates of heritability for fat and protein \% were higher than that for milk yield. Many authors such as Castillo-Juarez $\boldsymbol{e}$ al (2002); Samore et al (2002); Kadarmideen et al (2003); Lopez-Villalobos and Spelman (2009) and Abdullahpour et al (2010) reported heritability values of fat and protein $\%$ less than the present finding.

It was concluded that the heritability estimates of most of milk traits increased across lactations. The increased values of heritability could be attributed to the increase in the value of additive genetic variance and reduction in values of permanent environmental components.

1.3. Heritability estimates of days in milk:

Heritability estimates for days in milk were found to be $0.11 \pm 0.07,0.17 \pm 0.07$, for first, second lactations, respectively. It was clear that the estimates increased with the increment of lactation number. The estimates were moderate in first and second lactations. The present estimates of days in milk in early lactations were similar to the findings of Behmaram (2010) who reported heritability estimates of DIM to be $0.16 \pm 0.05$ and $0.13 \pm 0.06$ in Montbeliarde and Sarabi cows, respectively. Silvestre et al (2005) reported the estimate for DIM of 0.19 which increased to maximum estimated value of 0.23 at mid lactation then decreased.
On the other hand, the current results were much higher than the findings of Atil et al (2001) and Ayied et al (2011) who found heritability of DIM as $0.089,0.043,0.020$ and 0.040 . On the contrary, higher estimates of DIM reported by Atay et al (1995). Furthermore, Abdel-Gader et al (2007) found heritability of DIM to be 0.17 .

1.4. Heritability estimates of dry period:

A high heritability estimates were obtained for dry period to be $0.53 \pm 0.11$ for second, lactation. Similar estimates were reported by Ayied et al (2011) who estimated heritabilities for dry period to be $1.0,0.31,0.60$ and 0.78 by least square analysis.

The high estimates of heritability for dry period disagree with the findings of Deokar and Ulmek (1997) and Suhail et al (2010) who reported heritability to be $0.09,0.06,0.08$ and 0.10, respectively. Also, Abdel-Gader et al (2007) reported low heritability estimate for dry period as 0.04 .

1.5. Heritability estimates of calving interval:

The results revealed that heritability estimates of calving interval were $0.18 \pm 0.08$, for second lactation. The present result agree with HaileMariam and Kassa-Mersha (1994) who reported the highest heritability or $\mathrm{CI}_{3}(0.093)$ followed by $\mathrm{CI}_{1}(0.015)$, with the lowest value for $\mathrm{CI}_{2}$ (0.002).

Similar results were reported by Biffani et al (2003) who mentioned that heritability estimates of CI increased from $1^{\text {st }}$ to $3^{\text {rd }}$ parities from 0.08 to 0.14 , and concluded that higher parities showed higher heritability estimates. Mostert et al. (2010) recorded highest heritability for CI in $3^{\text {rd }}$ lactation. Olori et al (2003) showed heritability value to be highest in $\mathrm{CI}_{1}$. Ulutas et al (2004) found heritability of CI between 0.07 and 0.16 .

Higher estimates of heritability for calving interval were measured by Islam et al (2004) as 0.38 . These findings are in consistence with the present study especially in last lactation.

1.6. Heritability estimates of days open:

Heritability of days open were estimated to be $0.31 \pm 0.09$ and $0.11 \pm 0.07$ for the first, second 
lactations, respectively. The estimates were high for days open as a fertility trait. Abdel-Gader et al (2007) reported heritability of DO to be $0.51 \pm 0.37$ by Harvey sire model.

The literature estimates of heritability for the previous trait were low as compared to the current results; 0.043 by Haile-Mariam and Kassa-Mersha (1994); 0.052 by Uchida (2001) and $0.067 \pm 0.005$ by Ghiasi et al (2011).

1.7. Heritability estimates of services per conception:

The results showed a very high heritability estimates for services per conception as $0.87 \pm 0.14,0.59 \pm 0.11,0.36 \pm 0.11$ and $0.39 \pm 0.21$ for first, second, third and fourth lactations, respectively. Theses results disagree with the finding of Biffani et al (2003); Islam et al (2004) and Ghiasi et al. (2011) who found the heritability of services per conception within the range from 0.02 to 0.08 . The results indicate that genetic improvement of these traits can be achieved through selection for these traits in breeding programs.

1.8. Heritability estimates of age at first calving:

Table (1): Estimates of heritabilities (on diagonal with SE between parenthesis), genetic (above diagonal with SE between parenthesis), phenotypic (below diagonal) correlations among productive and reproductive traits for the first lactation

\begin{tabular}{|c|c|c|c|c|c|c|c|}
\hline Trait & DIM & TMY & Fat \% & Prot. \% & SC & DO & AFC \\
\hline DIM & $\mathbf{0 . 1 0 7}$ & -0.144 & 0.675 & 0.560 & 0.213 & 0.990 & 0.676 \\
& $(0.070)$ & $(0.321)$ & $(0.265)$ & $(0.275)$ & $(0.154)$ & $(0.041)$ & $(0.157)$ \\
\hline TMY & 0.485 & $\mathbf{0 . 2 9 0}$ & -0.187 & -0.320 & -0.165 & 0.706 & 0.168 \\
& $(0.640)$ & $(0.090)$ & $(0.172)$ & $(0.177)$ & $(0.165)$ & $(0.127)$ & $(0.188)$ \\
\hline 305-MY & 0.209 & 0.613 & -0.851 & -0.922 & -0.690 & 0.741 & 0.381 \\
& $(0.612)$ & $(0.685)$ & $(0.112)$ & $(0.115)$ & $(0.120)$ & $(0.151)$ & $(0.164)$ \\
\hline Fat \% & -0.010 & -0.192 & $\mathbf{0 . 9 0}$ & 0.937 & 0.756 & -0.689 & -0.562 \\
& $(0.574)$ & $(0.205)$ & $(0.155)$ & $(0.028)$ & $(0.068)$ & $(0.153)$ & $(0.133)$ \\
\hline Prot \% & -0.078 & -0.170 & 0.651 & $\mathbf{0 . 9 5 1}$ & 0.731 & -0.689 & -0.509 \\
& $(-0.992)$ & $(-0.015)$ & $(0.433)$ & $(0.142)$ & $(0.077)$ & $(0.161)$ & $(0.141)$ \\
\hline SC & 0.150 & 0.056 & 0.281 & 0.224 & $\mathbf{0 . 8 7 1}$ & -0.204 & -0.267 \\
& $(-0.074)$ & $(-0.808)$ & $(-0.340)$ & $(-0.382)$ & $(0.148)$ & $(0.164)$ & $(0.150)$ \\
\hline DO & 0.771 & 0.462 & -0.274 & -0.272 & 0.094 & $\mathbf{0 . 3 1 3}$ & 0.833 \\
& $(0.658)$ & $(0.331)$ & $(-0.356)$ & $(-0.657)$ & $(-0.988)$ & $(0.092)$ & $(0.158)$ \\
\hline AFC & 0.084 & -0.002 & -0.143 & -0.096 & -0.029 & 0.076 & $\mathbf{0 . 4 3 1}$ \\
& $(-0.317)$ & $(-0.121)$ & $(-0.640)$ & $(-0.984)$ & $(-0.777)$ & $(-0.367)$ & $(0.103)$ \\
\hline
\end{tabular}

Age at first calving was a critical covariate and trait in the same time in analysis of the present data. AFC had a heritability estimates as $0.43 \pm 0.10$. The previous investigations revealed a substantial variation in heritability of AFC. High estimates were reported by Suhail et al (2010) as 0.48 and Ayied et al (2011) as 0.42.

On the contrary, low estimates of heritability were mentioned by Uchida (2001) as 0.10 and Abdel-Gader et al (2007) as 0.098. A high heritability estimate of age at first calving was expected to indicate that the correlation between phenotype and genotype of the individual was high and therefore, selection on the basis of individual's own phenotype should be effective, then direct selection for AFC should be considered in selection plan. It was concluded that the heritability of fertility traits in dairy cattle were lower than many other economically important traits. Moreover, the low heritability of fertility traits indicated that the influence of herd management and other environmental factors were greater than the genetic background. 
Table (2): Estimates of heritabilities (on diagonal with SE between parenthesis), genetic (above diagonal with SE between parenthesis), phenotypic (below diagonal) correlations among productive and reproductive traits for the second lactation

\begin{tabular}{|c|c|c|c|c|c|c|c|c|}
\hline Trait & DIM & TMY & Fat \% & Prot \% & SC & DO & DP & CI \\
\hline DIM & $\mathbf{0 . 1 6 6}$ & 0.882 & -0.698 & -0.747 & -0.313 & 0.298 & -0.692 & 0.189 \\
& $(0.077)$ & $(0.124)$ & $(0.224)$ & $(0.231)$ & $(0.230)$ & $(0.391)$ & $(0.274)$ & $(0.327)$ \\
\hline TMY & 0.573 & $\mathbf{0 . 4 9 0}$ & -0.241 & -0.246 & -0.143 & 0.027 & -0.452 & 0.113 \\
& $(0.493)$ & $(0.109)$ & $(0.151)$ & $(0.156)$ & $(0.164)$ & $(0.307)$ & $(0.169)$ & $(0.225)$ \\
\hline Fat \% & -0.212 & -0.250 & $\mathbf{0 . 9 7}$ & 0.975 & 0.736 & 0.584 & 0.795 & 0.363 \\
& $(-0.312)$ & $(0.347)$ & $(0.149)$ & $(0.027)$ & $(0.091)$ & $(0.288)$ & $(0.086)$ & $(0.188)$ \\
\hline Prot \% & -0.175 & -0.192 & 0.619 & $\mathbf{0 . 8 4 8}$ & 0.651 & 0.594 & 0.791 & 0.422 \\
& $(0.295)$ & $(-0.120)$ & $(0.988)$ & $(0.136)$ & $(0.109)$ & $(0.295)$ & $(0.095)$ & $(0.193)$ \\
\hline SC & 0.127 & 0.025 & 0.223 & 0.162 & $\mathbf{0 . 5 9 3}$ & 0.169 & 0.543 & 0.452 \\
& $(0.360)$ & $(0.224)$ & $(1.00)$ & $(-0.955)$ & $(0.117)$ & $(0.258)$ & $(0.136)$ & $(0.205)$ \\
\hline DO & 0.544 & 0.251 & 0.059 & 0.078 & 0.182 & $\mathbf{0 . 1 1 7}$ & 0.328 & 0.316 \\
& $(0.579)$ & $(0.371)$ & $(0.355)$ & $(-0.264)$ & $(0.262)$ & $(0.071)$ & $(0.286)$ & $(0.351)$ \\
\hline DP & -0.286 & -0.216 & 0.234 & 0.182 & 0.145 & 0.237 & $\mathbf{0 . 5 3 4}$ & 0.383 \\
& $(-0.128)$ & $(0.031)$ & $(1.00)$ & $(-1.00)$ & $(-0.335)$ & $(0.254)$ & $(0.113)$ & $(0.193)$ \\
\hline CI & 0.051 & 0.033 & 0.064 & 0.058 & 0.144 & 0.183 & 0.390 & $\mathbf{0 . 1 8 4}$ \\
& $(0.023)$ & $(-0.004)$ & $(0.317)$ & $(-0.370)$ & $(0.018)$ & $(0.164)$ & $(0.435)$ & $(0.079)$ \\
\hline
\end{tabular}

Estimation of genetic trends for different traits:

Genetic trends of the studied traits are presented in Figures ( 1 to 9 ) as estimated from the mean breeding values of these traits across the time period from 1998 to 2010 .

Figure (1) showed the genetic trend of total milk yield for first and second lactations throughout different years. Generally, genetic trends for the two lactations were positive and estimated to be 18.97 and $5.99 \mathrm{~kg} /$ year, respectively. For both lactations, a declined trend was observed in the beginning of period then increased gradually to be high around the year 2004 in first lactation compared to increased genetic trend around year 2001 in second lactation and continued to be static until 2008 in second one. A clear genetic improvement in this trait was found between 2004 and 2007 in first parity which indicates an increasing of breeding values and selection up on better sires in this period. The positive values of $b_{1}$ and $b_{2}$ suggest genetic improvement in the farm for total milk yield.

The present trends of TMY are similar to the finding of Syrstad (1974); Basovsky et al (1979); Weller and Ezra (2004); Gaidarska
(2009) but lower in its value. On the other hand, the current trends disagree with the findings of Ary-Ferreira et al (1995) and Effa et al (2011), near the results of Hossain et al (2001) and Nehara et al (2012) and higher than the estimates of Abdullahpour et al (2010).

Figures (2 and 3) showed the genetic trends of fat $\%$ and protein $\%$. All of the annual genetic trends were positive and estimated as 0.003 and $0.017 \%$ / year, and 0.006 and $0.016 \%$ / year for these traits, respectively. Although, genetic rends were all positive, the annual increase in breeding values for percentage traits was small especially in medium years. These results are near to the findings of Syrstad (1974); Basovsky et al (1979); Weller and Ezra (2004); Gaidarska (2009), close to the finding of AryFerreira et al (1995) for fat \%, but inconsistent with the same authors for other traits. Moreover, the current estimates are in agreement with Weller and Ezra (2004) and on the contrary of the estimates of Abdullahpour et al (2010).

Figure (4) showed the genetic trend of days in milk for the first and second lactation. As the present data were collected from high producing 
farm, the positive breeding values for days in milk are the best to allow more time for milking, subsequently, the first parity showed positive genetic trend (0.052 days/year) as compared to the second one (-0.344 days / year). The negative trend of DIM is similar to those of $\boldsymbol{E f f a}$ et al (2011) who indicated no genetic improvement in DIM. On the other hand, the positive trend is similar to that of Hossain et al (2001); Atil and Khattab (2005); Steri et al (2010); Hossein-Zadeh (2012) and Nehara et al (2012).

Annual genetic trend for dry period as given in Figure (5) was 0.995 day/year for second lactation, explaining that the genetic improvement of this trait was in the opposite direction in the herd. This trend agrees with Eriksson et al (2013).

Slight genetic improvement was found in age at first calving, regressed by -0.047 month/year, as given in Figure (6). Similar trend was observed by Amimo et al (2006) for AFC as -0.01 month/year which indicated a decrease in mean breeding values over different years. Also, Effa et al (2011) and Gunawan et al (2011) reported negative genetic trend for AFC. Contrarily, the present trend is in disagreement with Eriksson et al (2013).

Figure (7, 8 and 9) showed the undesirable positive genetic trend for days open, SC and calving interval in first and second lactations except for slight genetic improvement for DO in second parity. Regression coefficients for these traits were 0.181 and -0.223 days/year, 0.023 and 0.008 service/year as well as 0.743 day/year, respectively. The positive undesirable genetic trend of fertility traits ensured the antagonistic relationship between milk yield and fertility and could be attributable to absence of genetic scheme for improving these traits and only selection up on milk yield traits.

The current genetic trend of calving interval agrees with the findings of Mostert et al (2010) and disagrees with those of Atil and Khattab (2005); Amimo et al (2006); Effa et al (2011) and Gunawan et al (2011). Moreover, Eriksson et al (2013) reported unfavorable genetic trend for services per conception in first and second lactations. In addition, Abdullah and McDaniel (2000) and Pszczola et al (2009) found positive unfavorable genetic trend for days open.

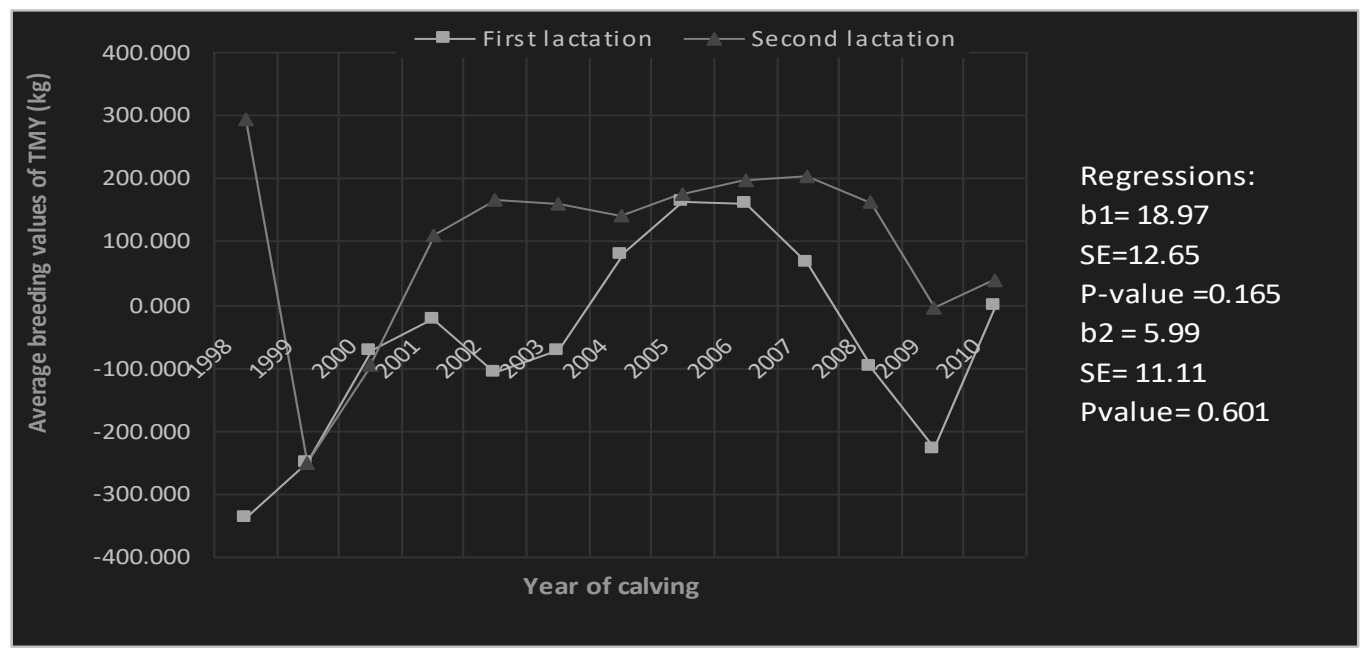

Figure (1): Genetic trends (mean breeding values) of total milk yield across year of calving for the first two lactation of production. 


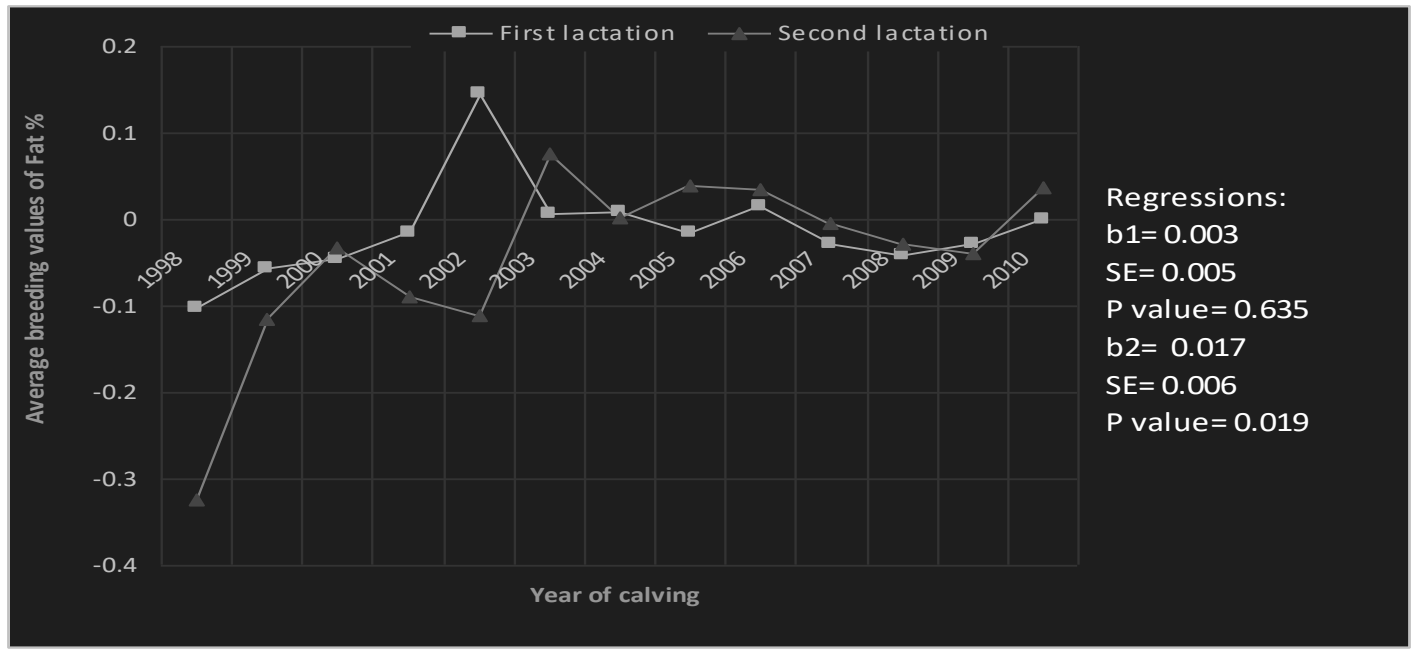

Figure (2): Genetic trends (mean breeding values) of fat percentage across year of calving for the first two lactation of production.

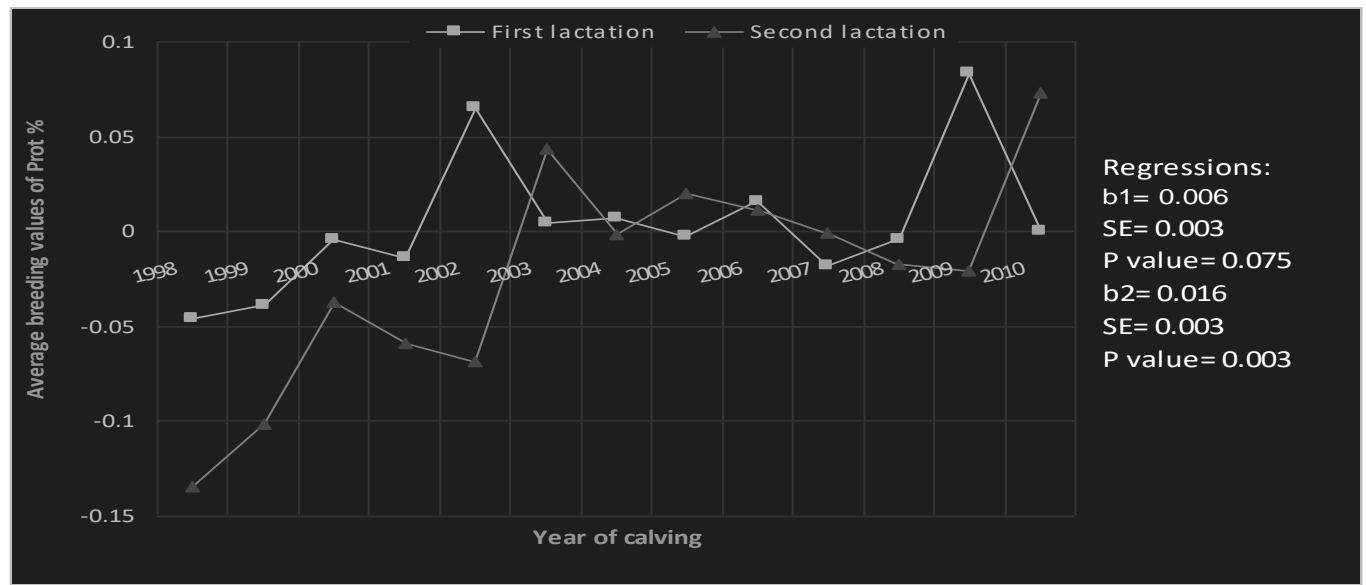

Figure (3): Genetic trends (mean breeding values) of protein percentage across year of calving for the first two lactation of production.

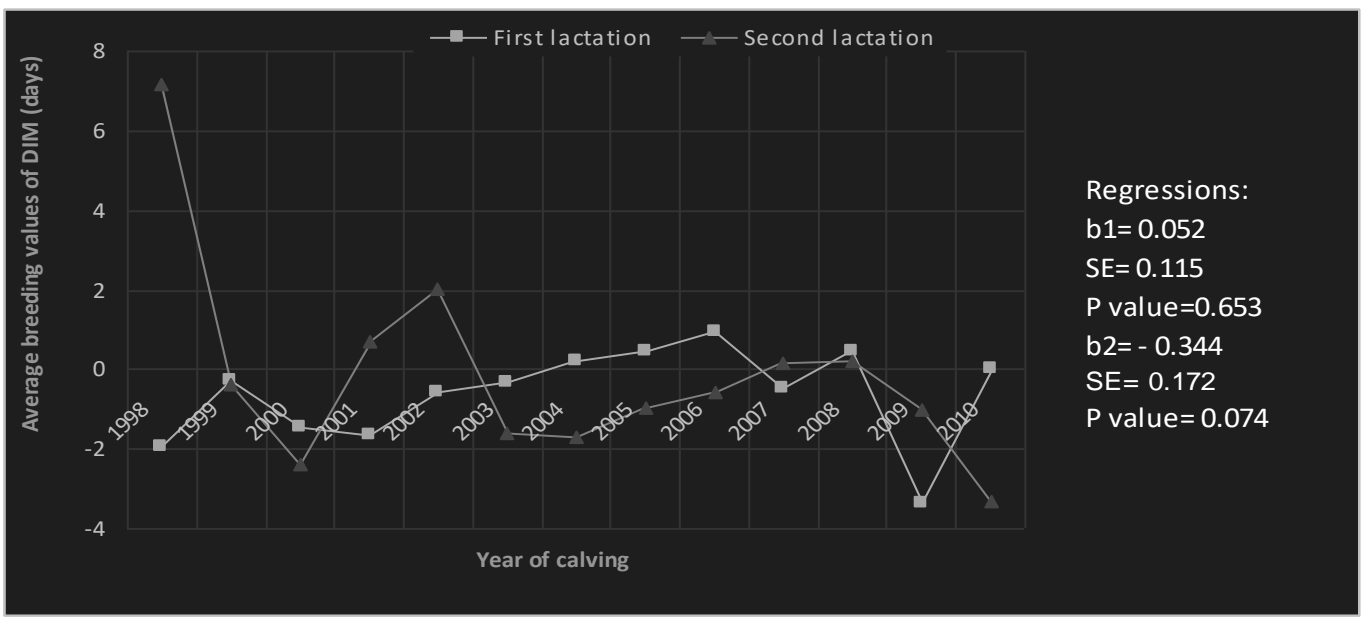

Figure (4): Genetic trends (mean breeding values) of days in milk across year of calving for the first two lactation of production. 


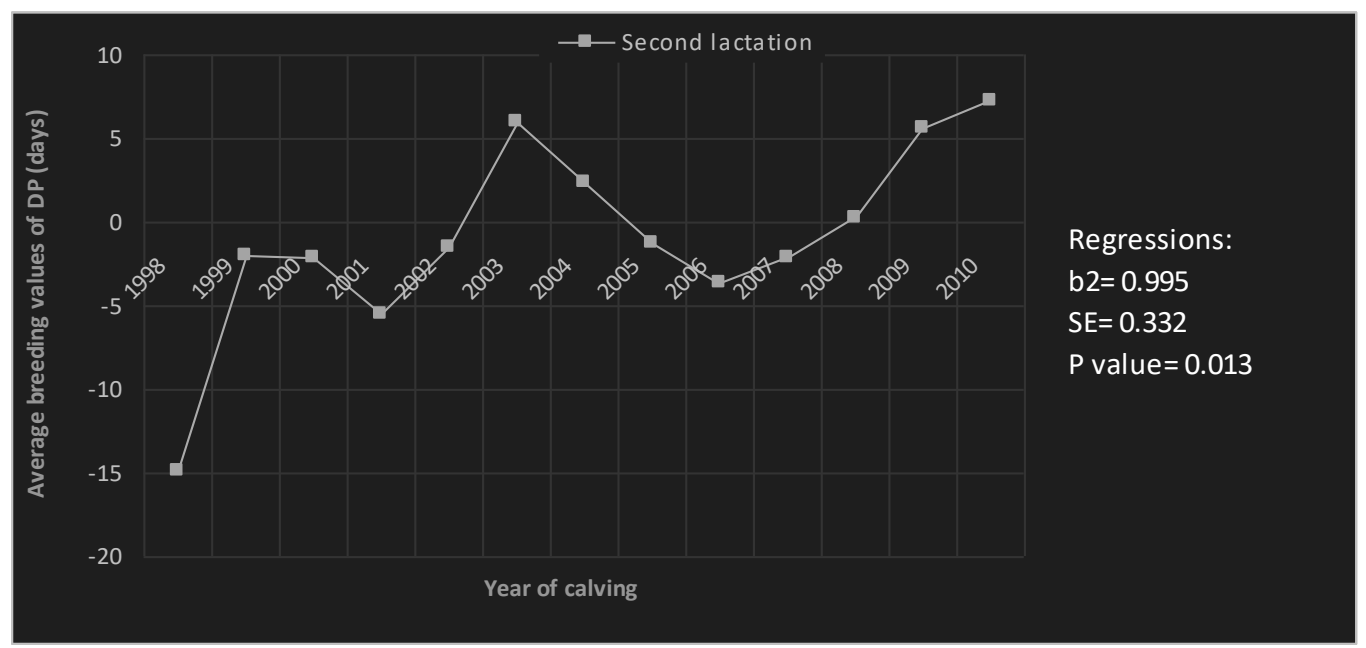

Figure (5): Genetic trends (mean breeding values) of dry period across year of calving for the second lactation of production.

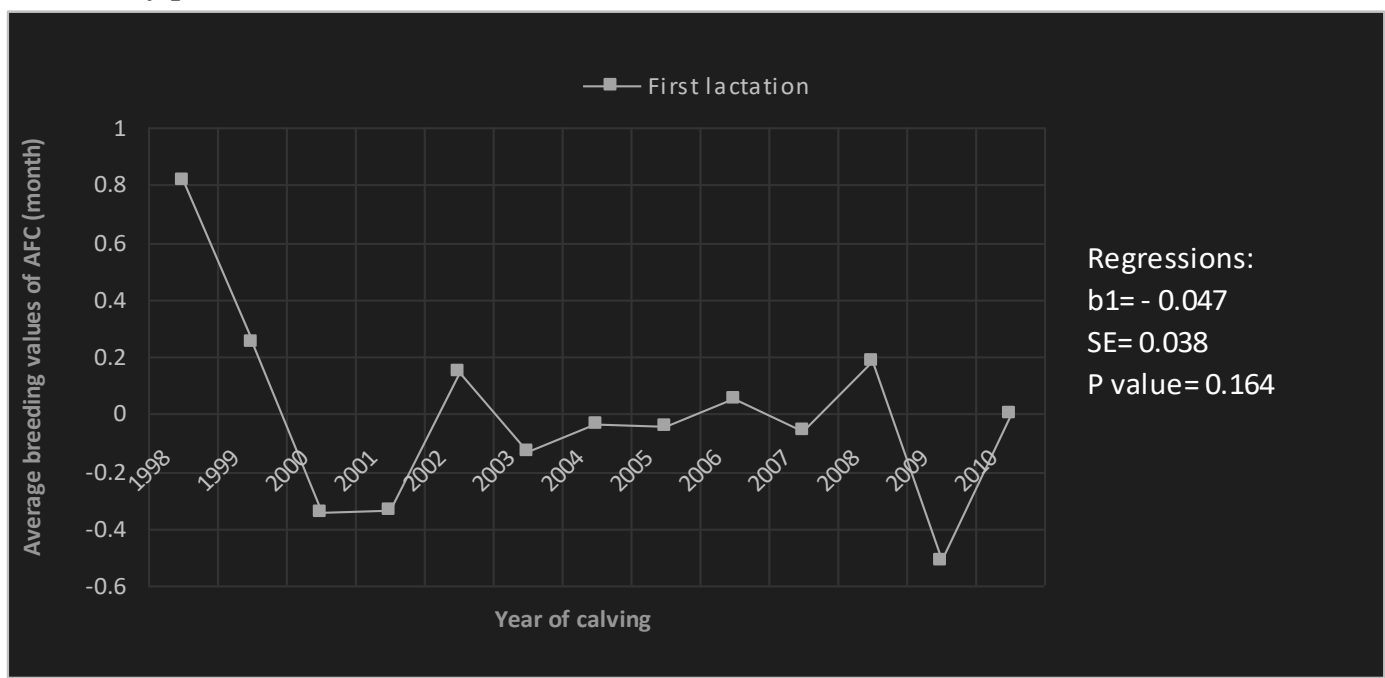

Figure (6): Genetic trends (mean breeding values) of age at first calving across year of calving for the first two lactation of production.

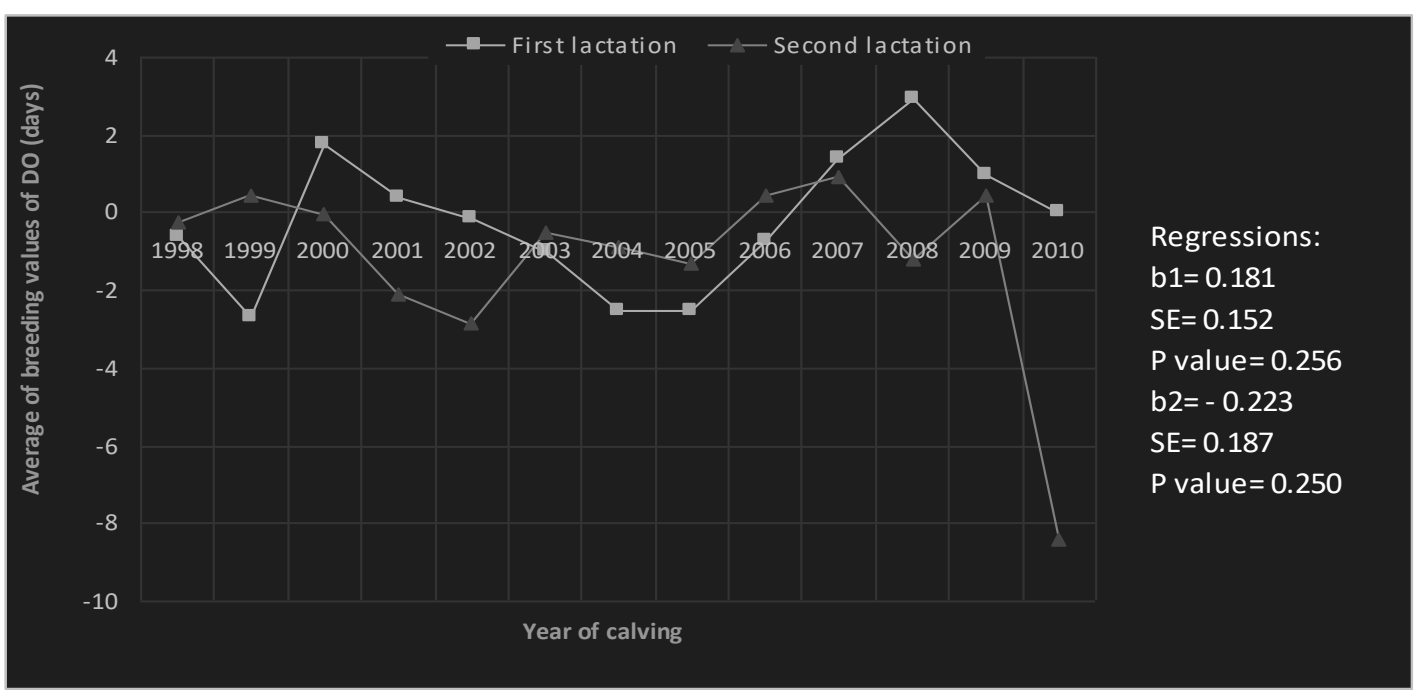


Figure (7): Genetic trends (mean breeding values) of days open across year of calving for the first two lactation of production.

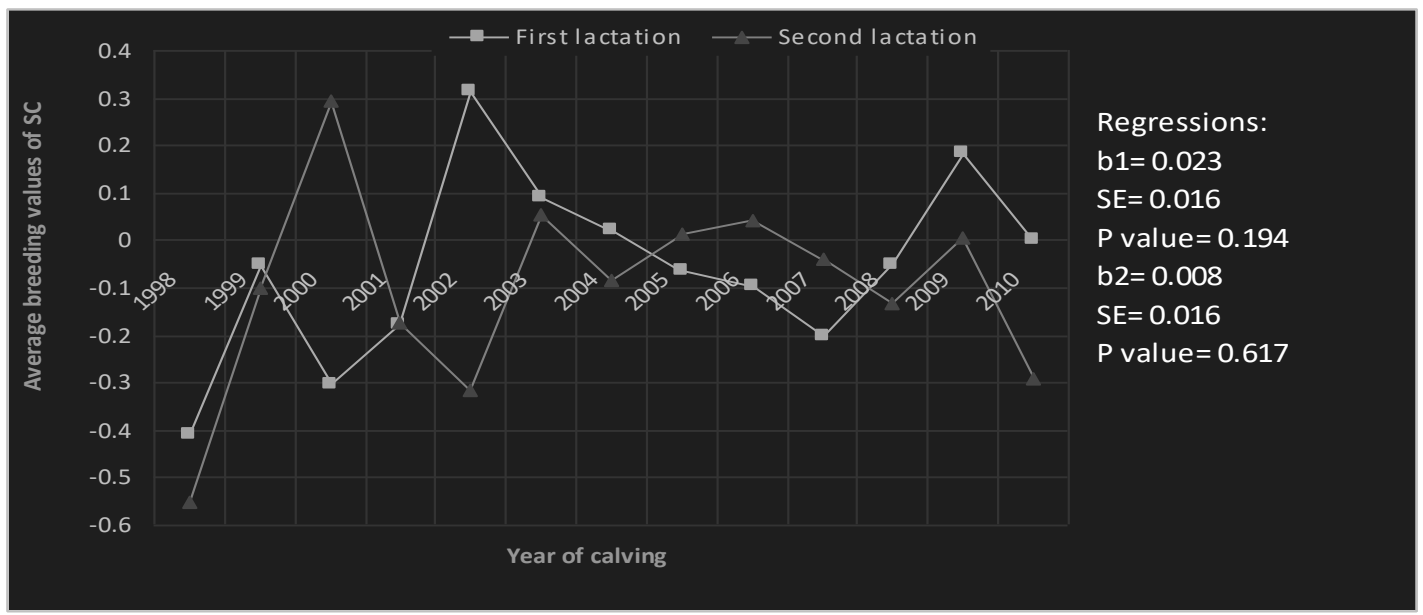

Figure (8): Genetic trends (mean breeding values) of number of services per conception across year of calving for the first two lactation of production.

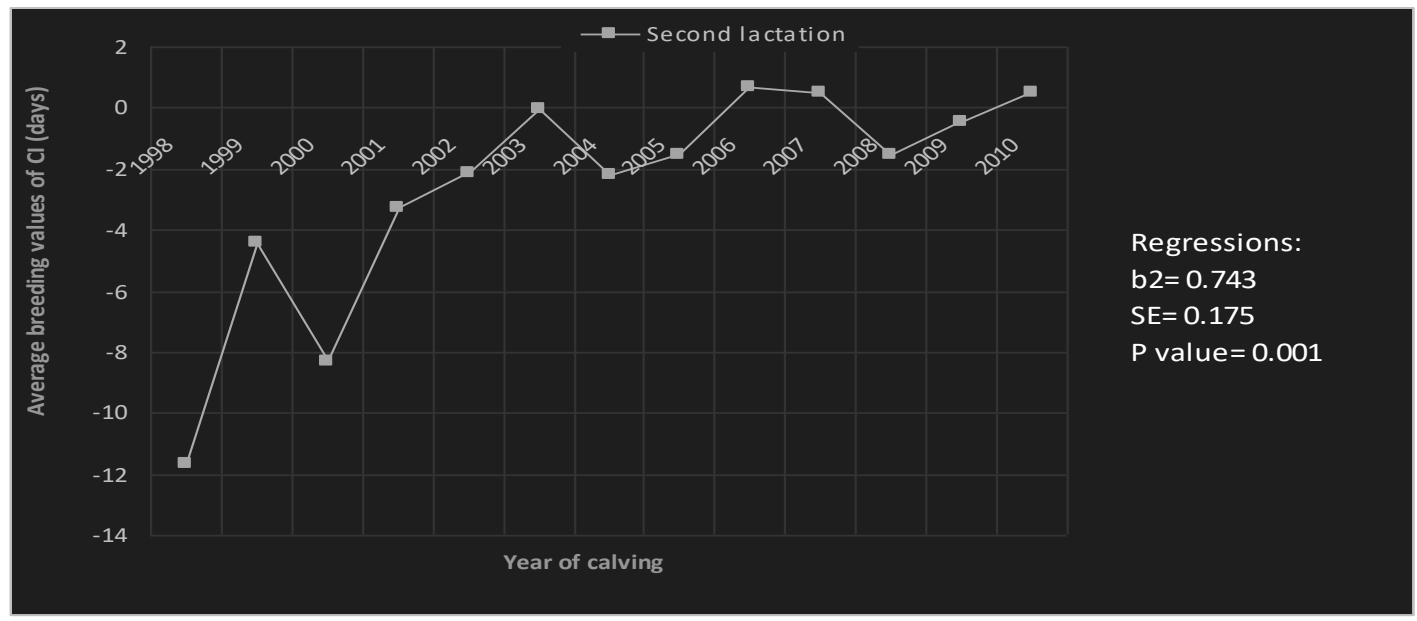

Figure (9): Genetic trends mean breeding values) of calving interval across year of calving for the first two lactation of production.

The high estimates of heritability for most of studied traits suggested that improvement of these traits would be achieved through selection. The high positive genetic correlations between traits especially productive ones clarified that these traits were likely to be controlled by the same number of genes so that these traits could be improved simultaneously through selective breeding. Moreover, positive genetic trends for most of studied traits are an index for the possibility of improvement of the current herd genetically.

\section{REFERENCES}

Abdallah J.M., B.T. Mc Daniel (2000): Genetic parameters and trends of milk, fat, days open, and body weight after calving in North Carolina experimental herds. J Dairy Sci., 83:1364-1370.

Abdel -Gader, A.Z., M. Khair, A. Ahmed, M.A. Lutfi and K.J. Peters (2007): Milk yield and reproductive performance of Friesian cows under Sudan tropical conditions. Arch. Tierz., Dummerstorf 50: 2, 155-164.

Abdullahpour, R., M.M. Shahrbabak, A. Nejati-Javaremi and R.V. Torshizi (2010): Genetic analysis of daily milk, fat and protein percentage of Iranian first lactation Holstein 
cattle. World applied sciences journal. 10 (9): 1042-1046.

Albuquerque, M.S.M., M.A.R. Freitas and T.R. Luiz (1999): Genetic and Phenotypic Parameters of Productivity Traits on the First Three Lactations in GYR Cattle Herds Genet. Mol. Biol.22 (2) 177-181.

Amimo J.O., R.O. Mosi, J.W. Wakhungu, T.K. Masaya and B.O. Inyangala (2006): Phenotypic and genetic parameters of reproductive traits for Ayrshire cattle on largescale farms in Kenya. Livestock Research Rural Development, 18 (10).

Ary Ferreira, D.F., J.W. Charles and C.N. Coata (1995): Genetic trends in the production of Brazilian dairy crossbreds. Rev. Brazil. Genet.18 (1): 55-62.

Atay, O., S. M. Yener, G. Bakir and A. Kaygisiz (1995): Estimates of genetic and phenotypic parameters of milk production characters of Holstein cows raised at the Ataturk forestry farm in Ankara. Turk J. Vet. Anim. Sci., 19, 441- 446.

Atil H., and A.S. Khattab (2005): Estimation of Genetic Trends for Productive and Reproductive Traits of Holstein Friesian Cows in Turkey Pakistan J. of biological sciences vol 8 (2), 202-205.

Atil H., A. S. Khattab and C. Yakupoglu (2001): Genetic analysis for ilk traits in different herds of Holstein Frisian cattle in Turkey. Journal of Biological Science 1(8): 737 741.

Aydin, A. (1996): Orobanßa dayanõklõ melez ay?i? araßtõrma. Basõlmamõß Doktora Tezi. Trakya Un. Fen Bilimleri Enstit.s. TekirdaÛ.

Ayied A.Y., A.J. Jadoa and A.J. Abdulrada (2011): Heritabilities and Breeding Values of Production and Reproduction Traits of Holstein Cattle in Iraq Journal of Basrah Researches ((Sciences)) Volume 37. Number 4 A / 15 August 66 -70.

Backer, W.A. (1984): A manual of quantitative genetics. $4^{\text {th }}$ Edition. McNaughton and Gunn, inc., Ann Arbor, Michigan.
Basovsky N.Z., B.M. Kuznetsov and B.M. Milovanov (1979): Prognosis of efficiency large selection. - Anews bulletin Vsirg, Leningrad, 41, 9-15.

Behmaram, R. (2010): Genetic parameters of productive traits in Montbeliarde and Sarabi cows. Research Journal of animal sciences, 4 (1): 40-44.

Berger, P.J., R. D Shanks, A. E. Freman and R. Laben (1981): Genetic aspects of milk yield and reproductive performance. J. Dairy Sci., 64: 114-122.

Biffani, S., R. Canavesi and AB. Samore (2003): Estimation of genetic parameters for fertility traits of Italian Holstein Friesian cattle. Conference paper, 54 ${ }^{\text {th }}$ annual meeting of the EAAP, Roma. Stocarstvo 59 (2): 145-153.

Campos, M.S., C.J. Wilcox, C.M. Becerril and A. Diz (1994): Genetic parameters for yield and reproductive traits of Holstein and Jersey cattle in Florida. J. Dairy Sci. 77, 867-873.

Carlen, E., E. Strandberg, and A. Roth (2004): Genetic parameters for clinical mastitis, somatic cell score, and production in the first three lactations of Swedish Holstein cows. J. Dairy Sci. 87:3062-3070.

Castillo-Juarez, H., P.A. Oltenacu, E.G. Cienfuegos-Rivas (2002): Genetic and phenotypic relationships among milk production and composition traits in primiparous Holstein cows in two different herd environments. Livestock Production Science 78: 223-231.

Choudhary, V., M.D. Kothekar, K.L. Raheja, N.N. Kasturiwale, D.W. Khire and P. Kumar (2003): Genetic evaluation of first lactation traits in Sahiwal cattle using restricted maximum likelihood technique. AsianAustralian J. Anim. Sci.16, 639-643.

Cilek, S. and S. Sahin (2009): Estimation of some genetic parameters (heritability and repeatability) for milk yield in the Anatolian population of Holstein cows. Archiva Zootechnica 12:1, 57- 64.

Deokar, D.K. and B.R. Ulmek (1997): Genetic studies on dry period in Jersey cattle. J. Maharashtra Agric. Univ. 22(3): 327-329. 
Dong, M.C., and L.D. Van Vleck (1989): Correlations among first and second lactation milk yield and calving interval. J. Dairy Sci. 72:1933-1936.

Effa, K., Z. Wondatir1, T. Dessie and A. Haile (2011): Genetic and environmental trends in the long-term dairy cattle genetic improvement programs in the central tropical highlands of Ethiopia Journal of Cell and Animal Biology Vol. 5(6), pp. 96-104.

Eriksson, S., W.F. Fikse, H. H. Axelsson and K. Johansson (2013): Genetic trends for fertility in Swedish Red cattle using different models. The EAAP conference (The European Association for Animal Production), take place in Nantes, France.

Gaidarska, V. (2009): Evaluation of genetic trend of the Bulgaria dairy population biotechnology in animal husbandry 25 (5-6), p 639-644.

Ghiasi, H., A. Pakdel, A. Nejati-Javaremi, H. Mehrabani-Yeganeh, M. Honarvar, $O$. Gonzalez-Recio, M.J. Carabaño and R. Alenda (2011): Genetic variance components for female fertility in Iranian Holstein cow. Livest. Sci., 45:1245-1249.

Haile-Mariam, M. and H. Kassa-Mersha (1994): Genetic and environmental effects on age at first calving and calving interval of naturally bred Boran (zebu) cows in Ethiopia. Anim. Prod. 58:329-334.

Harvey, W.R. (1990): User's guide for LSMLMW, mixed model least squares and maximum likelihood computer program. PC-2 version 2, Ohio state Univ., Columbus (Mimeograph), USA.

Hossein-Zadeh, N.G. (2012): Genetic parameters and trends for lactation length in the first three lactations of Holstein cows Archiv, Tierzucht. 55: 6, 533-539, ISSN 0003 - 9438.

Islam, S.S., A.R. Ahmed, A. Ashraf and N. Khanam (2004): Genetic and Phenotypic Parameters on Reproductive Traits of Crossbred Cattle in a Selected Farm of Bangladesh Pakistan Journal of Biological Sciences 7 (7): 1269-1273.
Kadarmideen, H.N., R. Thompson, M.P. Coffey and M.A. Kossaibati (2003): Genetic parameters and evaluations from single- and multiple trait analysis of dairy cow fertility and milk production. Livest. Prod. Sci., (81): 183195.

Lakshmi, B.S., B.R. Gupta, k. Sudhakar, M.G. Prakash and S. Sharma (2009): Genetic analysis of production performance of Holstein Friesian $\times$ Sahiwal cows. Tamilnadu J. veterinary and animal sciences, 5 (4) 143-148.

Legates, J.E. and E.J. Warwick (1990): Breeding and improvement of farm animals. $8^{\text {th }}$ ED., Cm (Mc Graw-Hill publications in the agricultural sciences.

Lopez-Villalobos, N. and R.J. Spelman (2009): Estimation of Genetic and Crossbreeding Parameters for Clinical Mastitis, Somatic Cell Score and Daily Yields of Milk, Fat and Protein in New Zealand Dairy Cattle. J. Dairy sci., 345-355.

Mostert, B.E., R.R. van der Westhuizen and H.E. Theron (2010): Calving interval genetic parameters and trends for dairy breeds in South Africa. The South African J. Animal Science available online at http:// www.sasas.co.za/sajas.asp.

Nehara, M., A. Singh, R.S. Gandhi, A.K. Chakravarty, A.K. Gupta, G.K. Sachdeva and R.K. Singh (2012): Phenotypic, Genetic and Environmental Trends of Milk Production Traits in Karan Fries Cattle Indian J. dairy Sci., vol 65, No 3.

Olori, V.E., M.H. Pool, M.P.L. Calus, A.R. Cromie, and R.F. Veerkamp (2003): Joint evaluation of survival and fertility in dairy cattle with a linear model. Interbull Bulletin 30, 20-24. Paul A.K., I. Singh, V.K. Bhatia (2003): A note on estimation of heritabilities of different dairy characteristics by different methods. Indian J. Anim. Res. 37, 153-154.

Petersen, M. L., L. B. Hansen, C. W. Young, and K. P. Miller (1986) Rates of milk flow and milking times resulting from selection for milk yield. J. Dairy Sci. 69:556-563.

Pszczola M., Aguilar I., I. Misztal (2009): Short communication: Trends for monthly 
changes in days open in Holsteins. J Dairy Sci 2009; 92:4689-4696.

Roman, R.M., C.J. Wilcox and F.G. Martin (2000): Estimates of repeatability and heritability of productive and reproductive traits in a herd of jersey cattle. Genet. Mol. Biol., 23: 333-339.

Samore, A.B., P. Boettcher, J. Jamrozik, A. Bagnato and A.F. Groen (2002): genetic parameters for production traits and somatic cell scores estimated with a multiple trait random regression model in Italian Holsteins 7th world congress on genetics applied to livestock production, august 19-23, 2002, Montpellier, France.

Silvestre, A.M., F. Petim-Batista and J. Colaco (2005): Genetic parameter estimates of Portuguese dairy cows of milk, fat and protein using a spline test-day model. J. dairy sci., 88:1225-1230.

SPSS, PASW Statistics 16: Release, 18.0.0. http://www.winwrap.com.

Steri R., A.A., Stanislao, F. Rotondo, C. Dimauro, A. Cannas, N.P.P. Macciotta and G. Pulina (2010): Genetic, technical and economics aspects of lactation length in dairy cows. Proceedings of the XXVI World Buiatrics Congress, 14-18 Nov., Santiago, Chile,

Strabel, T. and J. Jamrozik (2006): Genetic analysis of milk production traits of polish black and white cattle using large-scale random regression test-day models. J. dairy sci., 89:3152-3163.

Suhail, S.M., I. Ahmed, A. Hafez, S. Ahmed, D. Jan, S. khan and A. Rahman (2010): Genetic study of some reproductive traits of jersey cattle under subtropical conditions. J. Agric. Vol. 26, No.1, 87

Turner, H.N. and S.S.Y. Young (1969): Quantitative Genetics in Sheep Breeding. Macmillan .Melbourne, Australia. (C.F. Abd ElRaoof, 1993).

Uchida, H. (2001): Perspectives of research and project in breeding of Japanese beef cattle. In: Proceedings of the 98th Congress of Japanese Society of Animal Science. P.15.

Ulutas, Z., N. Akman and O. Akbulut (2004): Estimates of genetic and environmental Co variances for 305-day milk yield and calving intervals in Holstein Friesian cattle. Turk. J. Vet. Anim. Sci., 28, 101-105.

Van Vleck, L.D., M.C. Dong, G.R. Wiggans, (1988): Genetic (co)variances for milk and fat yield in California, New York, and Wisconsin for an animal model by restricted maximum likelihood. J. Dairy Sci. 71, 3053-3060.

Weller, J. I., and E. Ezra (2004): Genetic analysis of the Israeli Holstein dairy cattle population for production and nonproduction traits with a multitrait animal model. J. Dairy Sci. 87:1519-1527. 


\title{
الملخص العربي
}

"تقدير المكافئات الوراثية ، الإرتباطات الوراثية ، الإرتباطات المظهرية والإتجاهات الوراثية للصفات الإنتاجية

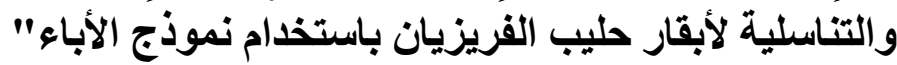

\author{
محمد منصور عثمان ، خيرى محمد البيومى' ، شريف عبد الرحمن معوض

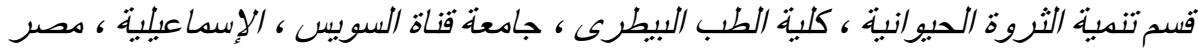

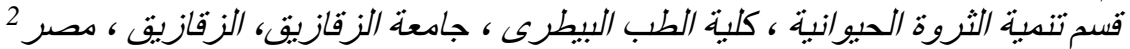

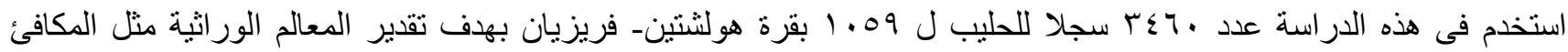

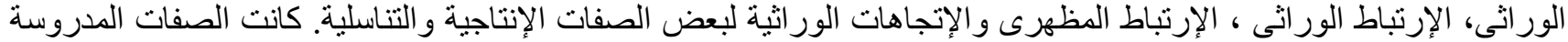

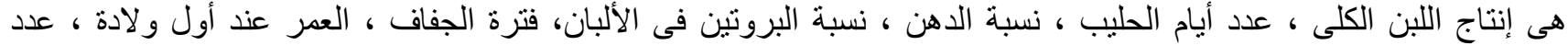

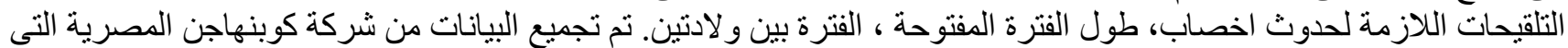

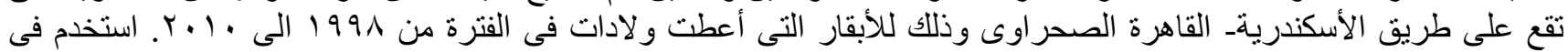

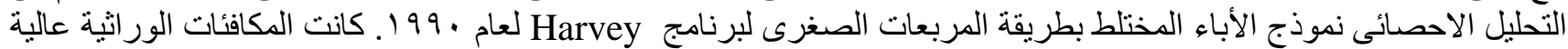

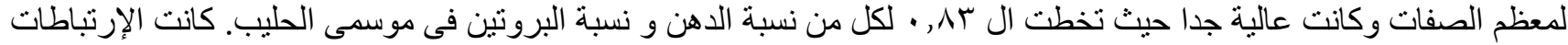

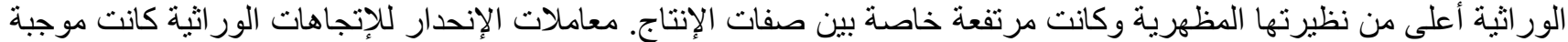

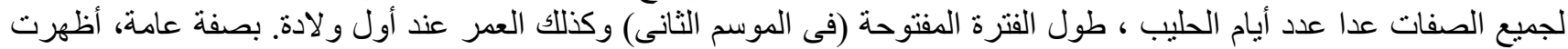
النتائج الحالية تحسنا ور اثيا لمعظم الصفات الصن والذى بذور الفره يعكس كفاءة بر امج الانتخاب. 